\title{
AC 2008-2574: TIPPING THE SCALES: FINDING THE MOST EFFECTIVE BALANCE BETWEEN LECTURE VERSUS ACTIVE LEARNING ACROSS ACADEMIC LEVELS IN ENGINEERING
}

\section{Beverly Jaeger, Northeastern University}

Dr. Beverly Jaeger is a member of Northeastern University's Gateway Team, a group of faculty expressly devoted to the first-year Engineering Program at Northeastern University. The focus of this team is on providing a consistent, comprehensive, and constructive educational experience that endorses the student-centered and professionally-oriented mission of Northeastern University. Teaching across all academic levels, she is also affiliated with the Department of Mechanical and Industrial Engineering at Northeastern University.

\section{Margaret Bates, Northeastern University}

Maggie Bates received a B.S. in History. from Salem State College, and an M.S in Human

Resource Counseling. and M.Ed. in College Student Personnel from Northeastern University, where she is currently a member of the Engineering Student Services staff. She serves primarily as an academic advisor to upper-class Chemical and Civil Engineering students. In addition, she teaches with engineering faculty members in Northeastern University's Introduction to the Study of Engineering course for first-year engineering students.

\section{Brittany Damon, Northeastern University}

Brittany Damon and Alison Reppy are 5th-year students in the 5-year Industrial Engineering Programming at Northeastern University. These juniors each have had 3 cooperative learning experiences, working outside the university in IE and have taken a strong interest in Motivation and Learning in Engineering Education, undertaking this research above and beyond their course and career work.

\section{Alison Reppy, Northeastern University}

Brittany Damon and Alison Reppy are 5th-year students in the 5-year Industrial Engineering Programming at Northeastern University. These Seniors each have had 3 cooperative learning experiences, working outside the university in IE and have taken a strong interest in Motivation and Learning in Engineering Education, undertaking this research above and beyond their course and career work. 


\title{
Tipping the Scales: Finding the Most Effective Balance between Lecture and Active Learning across Academic Levels in Engineering
}

\author{
I hear and I forget, I see and I remember, I do and I understand. -Confucius
}

\begin{abstract}
As seen in the quote above, the concept of active learning can be traced back to the time of Confucius (551-479 BC). Of late, much work and research has been done on the effectiveness and engagement value of experiential education ${ }^{1,2,5,6}$. Research indicates that in the proper measure and implementation, lessons can be successfully embedded into well-planned activities to illustrate and/or supplement the course lecture content to effectively educate students as young engineers ${ }^{2}$ and simultaneously challenge and inspire them ${ }^{5}$. However, with the current trend of incorporating more active learning into our curricula, we are mindful that a "one size fits all" approach may not be the best option to achieve the most success for all classes and levels in engineering. This research sets out to identify the framework for a proportional profile of learning modes across academic levels in engineering, starting with the freshman year and tracing on through to the senior year. Strong correlations between the infusion of carefully selected and implemented active learning modes and metrics of amount learned and overall teaching effectiveness have already been established. Thus, we extended the research to investigate the perceived value and effectiveness of active learning (AL) versus traditional lecture (TL), primarily for core engineering courses. This follow-on work sought to assign percentage approximations to the ideal balance of AL vs. TL at various engineering class levels.
\end{abstract}

Our premise was that, as students mature academically, their requirements concerning class design will also change and they will change in such a way as to be different from each other across progressive levels. Essentially, we expected linear incremental change. Students across three academic levels were surveyed on several elements of class presentation and the results were insightful in terms of the ratio of active learning to traditional lecture and the reasons for the perceived effectiveness of each. In general, the first-year freshmen engineering students preferred more AL to TL in a 55:45 ratio, third-year middlers expressed a significantly lower inclination toward active learning at 40:60, while surprisingly the fifthyear seniors reported their overall AL:TL proportion at approximately $60: 40$, reversing back to a ratio higher than the freshmen. Further enquiry was made as to the rationale for these profiles as well as what motivates and engages students in class. The responses are presented and evaluated in light of academic year (level), learning style, and GPA to determine which, if any, of these factors have a bearing on the results.

\section{Introduction}

Philosophical and Sociological Elements. As noted above, the notion of experiential learning has been in existence since the time of Confucius. Active learning, particularly in engineering, exhibits a decided concentration on group work and collective learning experiences. Marx and Engels also observed that the production of goods and services requires the "creative capabilities of individuals" and that these individuals be "inherently social" (Ritzer, 2000). George Herbert Meade, one of the later classical sociologists also shared this belief on a more micro-sociological level with his view that society as a whole develops the mind and actions of the individual through a series of social processes ${ }^{11}$.

"We are not in social psychology, building up the behavior of the social group in terms of the behavior of separate individuals composing it; rather, we are starting out with a given social whole of complex group activity, into which we analyze (as elements) the behavior of each of the separate individuals composing it..." 
While there are several sociologists and social psychology scholars who have long believed in the concept of active participation influencing society in general, the notion of using group work, hands-on activities, competition, serious games, and experiential learning as educational tools has been an important topic that has only recently been developed and incorporated into curriculum construction among educators over the past several years. Thus, it is important to remember during the redevelopment of a curriculum with this new focus, that we also be mindful of similar observational commentary and, in a way, "borrow" and be guided by their notions of varying processes impacting differently for numerous societal needs. In the fields such as business and engineering, teams of individuals are involved from the design phase to actual delivery of the product or service, indicating that society as a whole benefits from several individuals working together and having an investment in the process. In the ideal curriculum, learners would pass through these three stages: (1) new learners initially engage collectively in active learning to grasp new concepts; (2) as these learners progress, they take in additional information through more conventional learning while exploring some of their individual creativity and capabilities, and finally (3) they collectively come back together in committing to be involved in their own learning.

\section{Psychological and Educational Elements}

Pedagogy and Andragogy. The concept that adult learning (andragogy) is different from that of children (pedagogy) has been around for a number of years. Martin Knowles, a champion of andragogy and adult education believed that adults typically are self-directed towards their learning, and therefore inclined to want more involvement in the process. They also want to relate learning to their life experiences, understanding that education is for life. Young learners, on the other hand, have little experience to draw on, and therefore tend to be dependent on the instructor for guidance. They are also motivated to learn more by reward and punishment, i.e. good grades, failing grades ${ }^{4}$. Typically, the traditional lecture is based on the pedagogical model, with the professor providing information to the student, while the andragogical model allows for more interaction and cooperation between the student, peers, professor, and subject matter (active learning). With both approaches, effective learning can occur. Yet, what we can see from this is that different times can call for different measures; quite literally what is good for one is not necessarily good for all. So the question before us is how do we use these models to help strengthen the stages in our students' development as engineers?

Vygotsky and ZPD. The psychologist Vygotsky has influenced many educators with his ideology that knowledge consists of the combined contribution of a group of several individuals. Vygotsky's most significant contribution to education is a concept known as the Zone of Proximal Development (ZPD) $)^{9,12}$ with this concept, Vygotsky suggests that at a particular junction in a new learner's development, he can solve problems in a specific range only with the guidance and cooperation of others, including his peers. Once the new learner processes these problem-solving exercises internally, he can begin to undertake them independently ${ }^{9}$. This illustrates the distinction between pedagogy and andragogy in terms of learning requirements. Vygotsky's work also supports the concept mentioned previously whereby learners go through three stages of learning in moving from the pedagogical to the andragogical model for the ultimate purpose application in the real-world (RW).

The following studies have indicated that the use of varied educational methods can improve the effectiveness of teaching and increase the amount of information students can retain. A study on the psychological and physiological attention spans revealed that during a traditional lecture, only $70 \%$ of content could be recalled from the first ten minutes of lecture and a mere $20 \%$ from the last ten minutes ${ }^{3}$. It has been concluded that a "more radical device for maintaining attention requires breaking up the lecture" which we know can be achieved through the use of active learning techniques ${ }^{7}$. Additionally, it is the "hands-on" dynamic that often makes it more enjoyable for students and educators alike, not only by 
helping to improve class interest, involvement and participation, but also indirectly by promoting student retention in their chosen programs because of the inherent attraction it generates.

Educators such as J. Patrick McCarthy and Liam Anderson believed that active learning provides students the opportunity to learn material at a deeper intensity, while the traditional lecture provides the opportunity for students to learn only on a more superficial level ${ }^{6}$. They were interested in exploring effectiveness more than interest, so two experiments were conducted using role-play and problem solving versus the traditional lecture. Both of these courses were conducted in classes at the introductory level. Their results concluded that students retained material in class at a more profound level when engaged in active learning than those who learned the material through the traditional lecture method ${ }^{6}$. However, other educators such as, Raines and Rochester, having observed more balanced results, argue that a mix of both active learning and traditional lecture is warranted ${ }^{10}$. So what is the right formula? Furthermore, on what basis can we begin to determine this?

Motivation for this Work. Having recognized the merits of active learning, there are consequent propositions to make inquiries about how to determine whether all of its value is being realized. These include: Can there be too much active learning and if yes, how much is too much? When is it most effective? When is it least effective? Is the notion of traditional lecture all bad? In focusing so much on the "inherent good" of AL, are we being blinded to and therefore ignoring and effectively muting the benefits still to be gained from TL? This study is a step in generating a profile of how to establish the right blend of AL and TL for the course type and student level. Experience and observation on the part of students and instructors alike in engineering education has indicated the need to identify the optimal balance among different types of educational methods. This is useful in order to determine the effectiveness -and therefore usefulness- of these tools and techniques, in particular across the academic levels. From our experience and from this work we are learning that what works for a first-year freshman for knowledge, retention, and motivation is not necessarily as effective for our third-year middlers or our fifth-year seniors.

The engineering curriculum at Northeastern University is unique in that in spans over the course of a fiveyear period, with students working at two to three co-operative education jobs throughout their academic tenure. The benefit of co-op, however, causes complications in the development of course structure as students theoretically begin their academic career requiring a more pedagogical (instructive) approach to learning and leave with a more andragogical (self-directed) approach -or they are at the bridging stage in between these two points ${ }^{4}$. Essentially, this implies that the teaching techniques used in the classroom should evolve concurrently with students' academic and professional maturation and in accordance with their general learning styles and perferences.

This research project resulted from an acknowledgment of the inherent value of experiential and engaging learning modes, along with the recognition that they must be applied appropriately with regard to several factors. The movement to adopt AL techniques because of their potential benefits must be accompanied by an informed approach that considers factors such as academic level, professor's teaching style and strengths, course type, class length and duration, and students' learning styles, to name a few.

\section{Methodology}

Following an initial pilot testing, a mixed-format survey was developed further in an attempt to address some of the questions above. At the end of the Fall 2007 semester, the survey was administered in several engineering classes at 3 of the 5 student levels at Northeastern University. As noted above, the targeted populations were first-year freshmen, third-year middlers, and fifth-year seniors, all in the college of engineering in a variety of majors. Participation was voluntary in the data collection process. 
Subjects. The participants $(N=144)$ comprised a sample of convenience drawn from multiple engineering classes at Northeastern University. The sample sizes and gender demographics are set out in Table 1 below. Most of the outcomes addressed in this paper are based on these sample sizes, with the exception of occasional non-responses.

Table 1. Sample Sizes and Gender Demographics for Three Groups Surveyed.

\begin{tabular}{||c|c|c|c|c|}
\hline \hline YEAR: CLASS & Sample Size & Mean Age, yr & Male & Female \\
\hline 1: Freshmen & 50 & 18.24 & 37 & 13 \\
\hline 3: Middlers & 52 & 20.44 & 43 & 9 \\
\hline 5: Seniors & 42 & 22.46 & 36 & 6 \\
\hline
\end{tabular}

Survey Components and Administration. The three-page survey that was administered can be found in Appendix A. It was conducted during class time, taking approximately 15 minutes to complete. Full disclosure of the research objectives was provided to the participants at the outset, both verbally and in the written instructions, with the emphasis to the students being that their candid opinions were most valued. Anonymity, and thus confidentiality were assured and all supporting professors and participants were free to request the results of the research for their own edification. Students were asked to provide the following demographic information: age, gender, academic year, QPA, and major. Next, the questionnaire portion was presented. The format was a mixture of 7-point Likert-scale questions, with associated commenting opportunities as well as directed open-ended questions and checklists. Students were also asked to provide their recommendation for percentages of active learning versus traditional lecture for their particular academic level.

\section{Results and Discussion}

Areas of Concentration. This paper addresses only a subset of the questions and data gathered from the extensive survey, with a view to continuing this work and exploring the findings and considerations in greater depth at a future stage. The areas of concentration for the first phase of this work are set out below. The descriptive term for each question is placed after each number.

1 - TL Effective: Do you consider lecturing to be an effective method of teaching?

2 - AL Effective: Do you consider active learning to be an effective method of teaching?

1a - Better Lecture: What makes one person's lecture (not just their class) better than another's lecture? $1 \mathrm{~b}$-Lecture Courses: Is there a type of engineering class that is better suited to lecture than others?

9 - Percentages: With percentages that sum to 100 , create your ideal combination of teaching techniques for your current academic year. Ex). 1\% active learning $\mid 99 \%$ lecture

9 - \% Explanation: Briefly explain why below.

12: Retention Techniques: What teaching technique(s) would most help to improve your retention of course material at your current level in your education? Please explain:

TL vs. AL Effectiveness. Directly after the demographics portion of the survey, students were asked their opinion ratings on whether lecturing is an effective method of teaching. On a 7-point scale, the results are depicted in Figure 1 and shown in Table 2 below. 


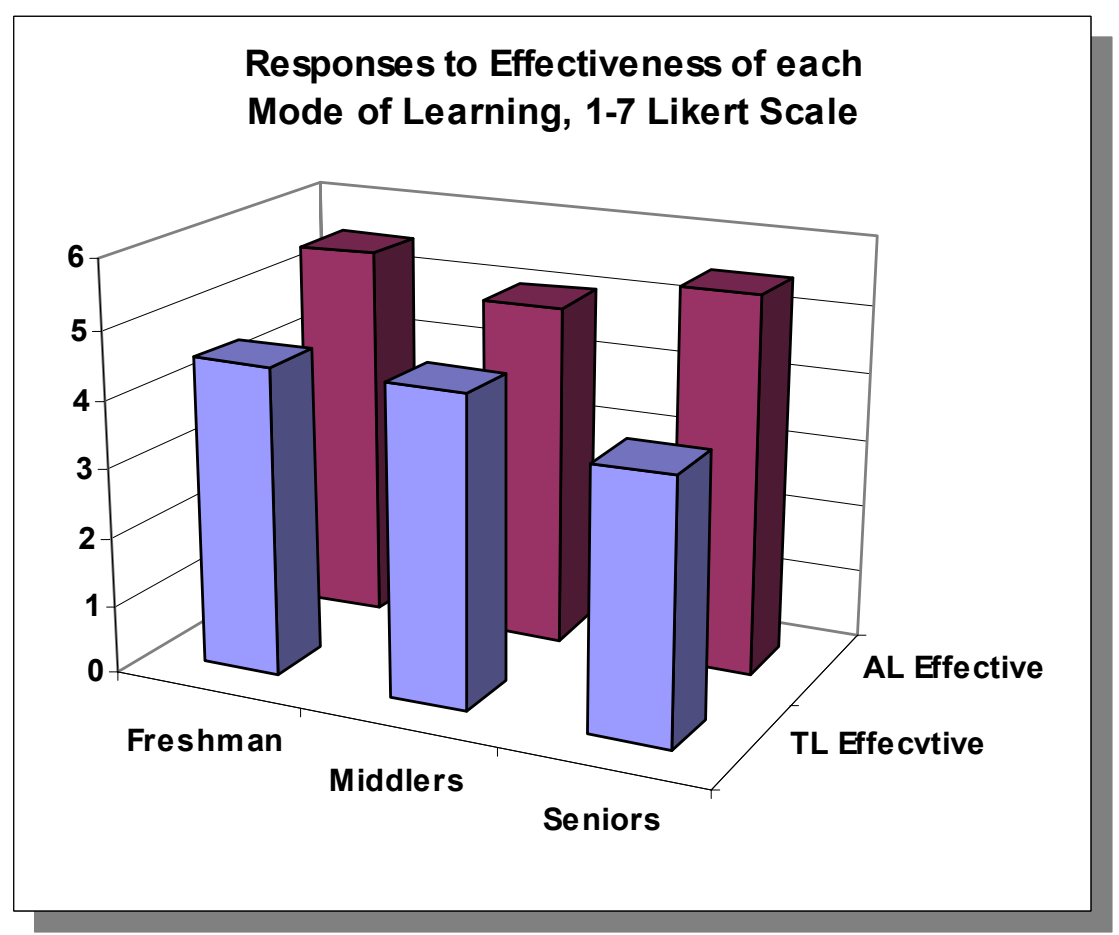

Figure 1. Responses across academic levels to effectiveness of learning modes.

Referring to Figure 1 and Table 2, not surprisingly all three of the academic levels regard active learning as more effective than traditional lecture. This difference is highly significant in the case of the freshman $(p<0.0002)$ as well as for the seniors $(p<0.0001)$, but not for the middlers. It appears that the middlers are seeking more of a balance. Another interesting set of observations across the levels in the profiles is the significantly lower effectiveness of lecture for the seniors $(p<0.001)$ as compared with the younger groups and the significantly lower effectiveness of active learning indicated by the middlers as compared to the ratings given by the freshman and seniors $(p<0.01)$.

Table 2. Sample Sizes and Gender Demographics for 3 Groups Surveyed.

\begin{tabular}{||l|c|c|c||}
\hline CLASS LEVEL & $\begin{array}{c}\text { Traditional Lecture } \\
\text { Effective? }\end{array}$ & $\begin{array}{c}\text { Active Learning } \\
\text { Effective? }\end{array}$ & $\begin{array}{c}\text { Statistical Significance of AL vs. TL } \\
\text { Differences Within a Level }\end{array}$ \\
\hline Freshmen & $4.5+1.31$ & $5.5+1.32$ & $p<0.0002$ \\
\hline Middlers & $4.5+1.39$ & $5.0+1.41^{*}$ & $\sim$ \\
\hline Seniors & $3.8+1.22 * *$ & $5.5+1.31$ & $p<0.0001$ \\
\hline \hline \multicolumn{2}{|r|}{ *Significant at $p<0.01$ from other two levels ** Significant at $p<0.001$ from other two levels, } \\
\hline
\end{tabular}

Elements of a Lecture that Make it Better. Students were then asked an open-ended question concerning what would make one lecture better than another. A multipass content analysis of the three academic levels of respondents revealed common primary factors that contribute to an effective lecture, but also resulted in some distinct differences in rankings of these factors. Results are presented by level in Figure 2 and seen listed in aggregate and numerical form in Table 3 below. The highest values are in highlighted cells. 
Table 3. Factors Named as Elements of a Better Lecture in Engineering Classes Shown Across all Levels.

\begin{tabular}{|l|c|c|c|c||}
\hline \multicolumn{1}{|c|}{ Factor(s) for a Better Lecture } & $\begin{array}{c}\text { Aggregate } \\
\text { Average } \%\end{array}$ & $\begin{array}{c}\text { Freshman } \\
\%\end{array}$ & $\begin{array}{c}\text { Middlers } \\
\%\end{array}$ & $\begin{array}{c}\text { Seniors } \\
\%\end{array}$ \\
\hline RW examples, demonstrations, visual aids (instructor-based) & 32.3 & 35.3 & 30.6 & 31.0 \\
\hline Ability to involve/interact with class/Hands-on (student-based) & 29.6 & 37.3 & 18.4 & 33.3 \\
\hline Professor's passion/Enthusiasm for subject and/or teaching & 28.4 & 45.6 & 18.4 & 21.4 \\
\hline Quality/Structure/Preparation/Organization of material & 28.3 & 28.4 & 30.5 & 26.2 \\
\hline $\begin{array}{l}\text { Communication/Presentation Skills: speaking English well } \\
\text { and clearly, not being monotone, good volume, writing clearly }\end{array}$ & 27.5 & 19.6 & 36.7 & 26.2 \\
\hline Information/Topic/Material itself is interesting to student & 8.9 & 13.7 & 6.0 & 7.1 \\
\hline Pace/Tempo of class suited to student and material & 7.5 & 6.0 & 0 & 16.6 \\
\hline
\end{tabular}

In terms of content analysis and generating discrete categories, a distinction was made between instructor-driven examples, demonstrations, and visual aids and student-centered, interactive hands-on, participative activities. Also, a differentiation was made to generate two separate categories related to the presentation of the material: one set of responses was geared toward the organization and arrangement of the lessons and the course, providing the students with a sense of structure and sequence that was sensible and orderly. The second grouping of presentation-related factors concentrated on the intelligibility of the professor in the verbal and written media. We found these to be relatively distinct in that different types of frustrations would emerge when these qualities were poorly implemented or entirely absent.

The aggregate averages of the respondents' percentages reveal a generic recipe to be an effective lecturer in the eyes of the students. Note that the top 3 averages are related to the activity level and energy in the classroom, whether from the professor or on behalf of the students. This is not at all surprising and validates results from previous work. A better "lecture" involves elements of active learning! As noted earlier, past research also evaluates the actual effectiveness of some of these AL techniques in terms of knowledge retention, amount learned and retained, supporting the use of active learning techniques. However, if the educator prefers to be in control of the classroom and oversee the time usage and delivery pace, there is further good news: If you are still not inclined to venture into lots of active learning, the number one aggregate response from the students for better lectures across the board are those in which the instructor provides real-world examples, conducts demonstrations and uses visual aids. None of these require the instructor to relinquish control of the classroom to the students, yet are still potentially highly effective.

However, with regard to differences across the academic levels, the aggregate values mask the resolution contained therein. The profiles of these factors are very different in each year of the programs that were sampled as seen in Table 3 above and depicted in Figure 2 below. Each academic level has a couple of critical distinctions that set it apart from the other groups, albeit that they were using the same ingredients to create the course structure. Most important to the freshmen is the professor's demeanor and energy, being even higher than active learning methods and real-world examples. This is not surprising as they express a desire for engagement and involvement in the classroom. The middlers placed a stronger emphasis on the clarity of communication, course and lecture structure and real-world applications. They appear to be more content-oriented and wish for the material to be delivered efficiently and succinctly as compared to the younger and older groups. Finally, the seniors distinguish themselves by demonstrating that their focus returns to active learning and real-world examples and applications. As they prepare to transition into the workforce, the applicability of what they learn and do in the classroom takes primacy and becomes their focus. They are essentially demanding an identifiable purpose to their time and activities. 


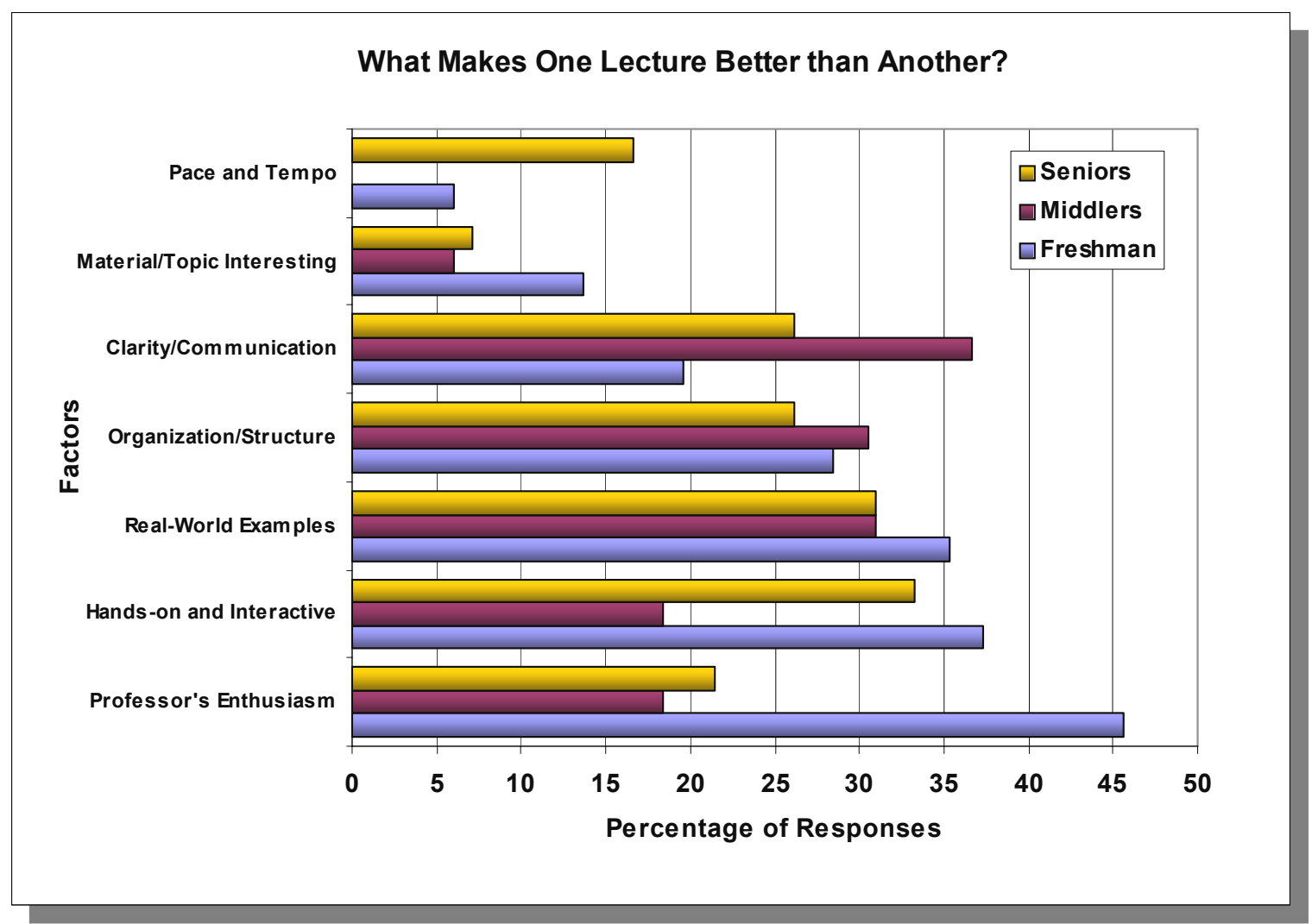

Figure 2. Responses to what makes one lecture better than another, shown across all academic levels.

In nearly every factor profile (shown in Figure 2), the seniors and freshmen follow similar patterns, but for very different reasons. One main exception is that the older students are not as affected by the demeanor of the professor as compared with the freshmen, but they do place an appreciable amount of emphasis on organization and clarity of communication - time must not be wasted in their estimation. Further, some seniors were specifically concerned with the pace and tempo of courses; this was an unexpected factor - and could likely be situational to NU. Comments regarding the tempo of the course focused on one of two scenarios in which students felt either the course progressed too slowly due to their prior knowledge and or the material in the course was very detailed and specific, requiring the course to move at a tedious rate. Regardless, this is a good factor to check in with the students on in mid-course assessments

Courses More Suited to Lecture. Next, students were asked to consider: Is there a type of class that is better suited to lecture than others? They were free to name any courses when responding. Results are seen in Tables 4-6 below, with the higher values found in shaded cells.

Table 4. Freshmen: Suitability of Courses for TL (Traditional Lecture) and AL (Active Learning).

\begin{tabular}{|l|c|c|}
\hline \multicolumn{1}{|c|}{ Class Type } & $\begin{array}{c}\text { 1b: Lecture } \mathbf{n = 4 1} \\
\mathbf{\%}\end{array}$ & $\begin{array}{c}\text { 2b: Active } \mathbf{n = 4 1} \\
\mathbf{\%}\end{array}$ \\
\hline Engineering Core & 5 & 49 \\
\hline Math/Science (Chemistry, Calculus, Physics) & 49 & 10 \\
\hline Math/Science \& Engineering Core (STEM)* & 3 & 13 \\
\hline Courses outside STEM & 3 & 5 \\
\hline None - No courses are suited to the specified mode & 15 & 5 \\
\hline "STEM: Science, Technology, Engineering, and Math based courses \\
\hline
\end{tabular}


Table 4 shows that while nearly half of the freshmen (49\%) believed that math and science courses were more suited to lecture, an equal percentage also believed that engineering courses (Engineering Design in particular) were more suited to active learning. An additional 13\% believed that STEM courses in general were more suited to active learning. The higher top values may be due to the fact that this is the first time that these students are exposed to engineering; thus, active learning allows them to grasp the complexities involved in the engineering curriculum. Further, this population has only had limited exposure to the other types of courses at the collegiate level, so this concentrated profile is not surprising.

Table 5. Middlers: Suitability of Courses for TL (Traditional Lecture) and AL (Active Learning).

\begin{tabular}{|c|c|c|}
\hline Class Type & $\begin{array}{c}\text { 1b: Lecture } \mathrm{n}=37 \\
\%\end{array}$ & $\begin{array}{c}\text { 2b: Active } n=36 \\
\%\end{array}$ \\
\hline Engineering Core & 9 & 25 \\
\hline Math/Science (Chemistry, Calculus, Physics) & 25 & 9 \\
\hline Math/Science \& Engineering Core (STEM)* & 11 & 20 \\
\hline Courses outside STEM* & 14 & 17 \\
\hline None - No courses are suited to the specified mode & 19 & 14 \\
\hline
\end{tabular}

As seen in Table 5, the disparity between learning mode preferences among the middler students was not as great compared to those of freshman. These students appeared to find both the TL class and the AL class almost equally effective. This could be due to the fact that the middler students have been exposed to more engineering courses, and thus neither need nor desire the extent of active learning that the freshmen students do. It is interesting that this group of students professed that both physics and engineering courses combined in particular were more suited for active learning.

The middler students' inclusion of active learning techniques benefiting physics courses, may have been influenced by Northeastern University's recent re-structuring of the fiscal academic schedule from quarters to semesters; thus, new course content has been assessed and adjusted over numerous iterations over the past several years in an effort to determine the correct material content. As such, it is not unlikely that their experience differed slightly from those of the freshmen and senior students.

Table 6. Seniors: Suitability of Courses for TL (Traditional Lecture) and AL (Active Learning).

\begin{tabular}{|l|c|c|}
\hline \multicolumn{1}{|c|}{ Class Type } & $\begin{array}{c}\text { 1b: Lecture } \mathbf{n = 3 7} \\
\mathbf{0}\end{array}$ & $\begin{array}{c}\text { 2b: Active } \mathbf{n = 3 6} \\
\mathbf{\%}\end{array}$ \\
\hline Engineering Core & 11 & 56 \\
\hline Math/Science (Chemistry, Calculus, Physics) & 3 & 3 \\
\hline Math/Science \& Engineering Core (STEM)* & 6 & 12 \\
\hline Courses outside STEM* & 0 & 0 \\
\hline None - No courses are suited to the specified mode & 19 & 6 \\
\hline${ }^{*}$ 'STEM: Science, Technology, Engineering, and Math based courses \\
\hline
\end{tabular}

In Table 6 , the seniors have a dispersion of opinion, with $56 \%$ believing that active learning is more suited to their engineering courses. An additional 12\% believed that active learning suited both math/science and engineering courses. Only 3\% of seniors believed that math/science courses were better suited to either lecture or active learning. However, we believe this disparity exists for reasons different from those expressed by the freshmen students. Essentially at this point, these students have already invested in and are comfortable with the curriculum. They have also developed the maturity to take a more active andragogical role in their own learning instead of relying solely on faculty to present the information. Their past middler time has also enabled them to formulate a solid foundation of information, now it is time for them to act on the framework. 
Percentages of Active Learning and Traditional Lecture. Prior to this research, theoretical notions and informal enquiry anticipated the outcome in this area to be an observed progressive shift in students' inclinations from low percent lecture/high percent activity to higher percent lecture/lower percent activity in the classroom over the course of their engineering programs. We have now learned that this is not necessarily the case! In analyzing the results, we have been able to identify a profile that changes with the students' motivation for learning and identifies the ratios of preferred learning modes. The results were not what we had initially expected. The AL:TL ratios are shown in Figure 3 below.

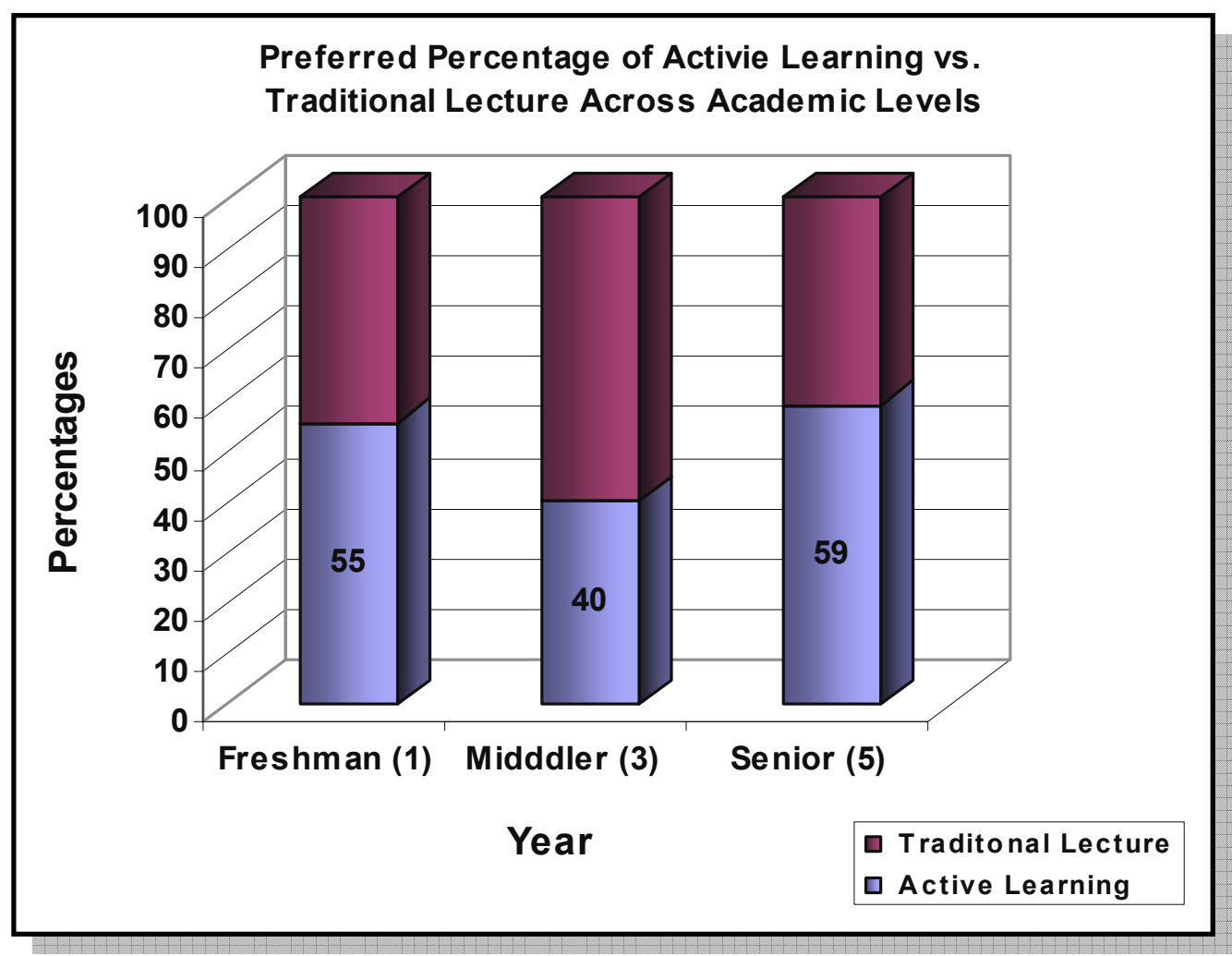

Figure 3. Percentages of active learning vs. traditional lecture at students' current level.

Although the results differ from our original hypothesis, they are not unwarranted and even underscore a distinct observation previously overlooked. As the student progresses from freshman to senior, the types of courses simultaneously evolve; freshman courses are often large, introductory level whilst senior courses are more specific with a higher professor-student ratio. Further, seen in the Table 7 below, the rationale becomes a significant driver for the preferred mode of learning. Freshman desire a higher percentage of AL for the purposes of engagement and interest, yet the seniors are seeking experiential learning with a distinct real-world practicality. We were correct in expecting that there would be change in the needs of the students over time; what had not been considered was that a similar solution might be best for more than one need (for different reasons). This is what was seen with similar Al:TL profiles for both freshman and seniors. By extension, one can assume that in industry, students will, in fact be doing, therefore to aid the transition from student to real-world participant, the final stage of education needs in many ways to emulate and mirror the first stage of employment. As such, it is understandable that in an effort to bring real-world applications to the classroom, students would expect to be doing rather than merely hearing and observing in their senior year. 
Table 7. Profile of Desired Level of Active Learning vs. Traditional Lecture in Engineering Courses.

\begin{tabular}{||c|c|c|c|l||}
\hline LEVEL & $\begin{array}{c}\text { ACTIVE } \\
\text { LEARNING }\end{array}$ & $\begin{array}{c}\text { TRADITIONAL } \\
\text { LECTURE }\end{array}$ & $\begin{array}{c}\text { AL }- \text { TL Sig Diff } \\
\text { w/i a Level? }\end{array}$ & $\begin{array}{c}\text { RATIONALE } \\
\text { PROVIDED }\end{array}$ \\
\hline Freshman $(n=50)$ & 55.5 & 45.5 & $\sim$ & $\begin{array}{l}\text { Engagement, Interest, } \\
\text { Retention, but Guidance }\end{array}$ \\
\hline Middler $\quad(n=52)$ & 40.1 & 59.9 & $p<0.0001$ & $\begin{array}{l}\text { Foundational, Instructive, } \\
\text { and Illustrative }\end{array}$ \\
\hline Senior $\quad(n=42)$ & 58.9 & 41.1 & $p<0.0002$ & $\begin{array}{l}\text { Practical and More Readily } \\
\text { Applicable to Real World }\end{array}$ \\
\hline
\end{tabular}

Explanation of Rationale for Active Learning and Traditional Lecture Ratios. In an effort to better understand the desire for Active Learning versus Traditional Lecture, students were asked to provide an explanation for the driving factor(s) in the selection of their ideal combination of AL and TL percentages for their current academic level. The results are shown in Table 7 above. Shaded cells indicate the highest value for each level. Not all respondents provided explanatory remarks for the percentages, but a listing of comments representing the common trends is provided below. All levels recognized that a combination of both active learning and lecturing can be appropriate in many cases. Representative remarks were:

- Freshmen, AL: "Courses should engage us, get us involved with the material, lecture teaches [while] active learning facilitates, active learning teaches better, lots of hands-on and a few lectures, active learning engages the audience, enhance learning by AL, lecture explains while AL gives students time to absorb what's being taught, AL keeps students better focused, lectures tend to be boring, lower academic levels would need more AL to keep them interested, lecture not as fun, easier course -less lecture, need labs to understand, enjoy AL"

- Freshmen, TL: "Need the basis of lecture, lecturing is more time-efficient, active learning [can] take too long, learn more in a lecture (but not as fun), intro classes need to be lecture, lectures are way better, a lot of the time lecture is appropriate“"

- Middlers, AL: "More is learned though experiential learning than just hearing -but some courses cannot be presented interactively, prefer doing [rather] than taking notes, a balance will make it more interesting, apply [concepts] to real problem solving in lab, should be some lecture and some active learning, AL keeps me interested, fundamental classes need more AL than theory-based upper level classes, AL [via] labs is helpful, [engineering courses] can be enhanced by active learning, more classes need AL, combination of the two"

- Middlers, TL: “Active learning techniques don't explain some things, learn concepts and problemsolving in lecture, learn more through lectures, lectures explain what is going on and why, lectures are more effective; too much AL cannot convey all material quickly, lecture is necessary, engineering courses require lecturing, basic classes should be lecture, combination of the two"

- Seniors, AL: “AL is useful to understand lecture, students choose engineering because [they] want to know how things work (not just the theory), being able to physically see and examine helps generate desire for learning, AL helps to understand the application of a theory to the real world, lectures put me to sleep, lectures are worthless unless applied to RW, Learning through experience teaches much more, good to have a balance, AL applies [material] to real life, AL reinforces the lecture, important to relate material to RW situations, lectures are boring, [lectures] don't teach anything, [lectures] have no application to the RW, [lectures] are an excuse for lazy teachers to do their job poorly, [need] AL to understand material, hands-on is easier to learn/retain, enjoy doing hands-on activities, instilling the knowledge is where AL benefits, theory and approximation classes are clearer with hands on, AL seems to stay with me longer, learn more through doing than from hearing, retain info better when seen in use" 
- Seniors, TL: "AL should be long enough to support the lecture material (but short enough not slow down the class), learn material in lecture, important to know [material in] lectures, need lectures for basics and background, some AL takes too much time, lectures are okay to learn how to solve problems and learn terms/methods (but not much else), activities to back up lecture and give hands on learning experience [are good], necessary to have lectures (but combined with AL), need lecture as a backbone, lectures are still needed for some courses, lecture goes over material while [AL] demonstrates applications, AL mixed in: explain then demonstrate with AL, good to know theories (but use AL to reinforce topics learned), lecture teaches the reasoning behind a concept while AL teaches how the concept is applied, AL takes time, lecture [teaches] basics behind theory and show through AL"

Reviewing the explanatory comments for themes and distinctions, it was first noted that all groups had an appreciable number of members who indicated that a balance or combination of learning modes would be in order. In identifying distinctive themes within the 3 levels, freshmen have a higher concentration on engagement and absorption through AL, but recognize the time-efficiency of TL for fundamentals. Middlers like the learning and reinforcement qualities of AL, while they also recognize -and to a considerable degree prefer- the instructive qualities of TL at their level. Finally, the seniors advocate a more advanced version of hands-on AL for the purposes of real-world relevance, practical application, and longer-term retention of the material. The value that seniors attribute to TL mode is primarily related to establishing theories and reasoning behind what they will practice and do with AL.

The profile in Table 7 again reiterates that seniors strongly gravitate back toward experiential learning, but for very different motivations from those of the freshman. The results may be due to the fact that freshmen students are trying to decide what it is they would like to do. Many freshmen have an undeclared engineering major and are seeking guidance regarding the engineering discipline most suited for themselves. Middler students, on the other hand, have more direction and essentially know what they want (at least to the type of engineering discipline they are most interested in pursuing) and are seeking to establish a solid foundation within that discipline Lastly, seniors have obtained a foundation of knowledge and seek to transition the knowledge gained in the classroom to workplace applications.

Teaching Techniques to Improve Retention of Material. Finally, we wanted to identify what would help students best retain the material and processes we are trying to teach them. Referring to Table 8, it is very interesting to note that middlers clearly recognize that active learning can help them retain and remember concepts, but -as seen from earlier data- they do not desire it as much as their older and younger counterparts. Although there are many additional factors to consider, some generalizations emerge from the strong trends seen in the data that are listed below Table 8 . These observations are discussed in the next section on Trends and Guidelines.

Table 8. Open-ended Responses Identifying Teaching Techniques that Assist in Remembering Concepts.

\begin{tabular}{||l|c|c|c|c||}
\hline Teaching Techniques to Help in Retention of Material & $\begin{array}{c}\text { Aggregate } \\
\text { Average } \%\end{array}$ & $\begin{array}{c}\text { Freshman } \\
\%\end{array}$ & $\begin{array}{c}\text { Middlers } \\
\%\end{array}$ & $\begin{array}{c}\text { Seniors } \\
\%\end{array}$ \\
\hline Interesting, Visuals/Demonstrations, Examples & 38.8 & 21.4 & 35.7 & 59.3 \\
\hline Activities, Hands-on, Creative & 36.4 & 38.8 & 49.9 & 20.5 \\
\hline Structure/Organization, Repetition, Quizzes/Tests & 25.8 & 35 & 14.3 & 28.2 \\
\hline Big Real-World Picture, Practical/Applied & 25.5 & 14.3 & 21.4 & 41.0 \\
\hline Quality of Professor & 9.0 & 7.0 & 7.0 & 13.0 \\
\hline
\end{tabular}


Trends and Teaching Guidelines. So, what have we learned form this set of enquiries that we can bring to our classrooms? The compelling findings are summarized below for our collective consideration.

\section{Freshmen:}

- tend to prefer more active learning to traditional lecture, but not significantly more.

- attest to appreciating the material when the professor is engaging and shows interest.

- Have preferences related to becoming interested in their field and formulating context.

- also have a high desire for real-world applications and examples to provide context.

- express a greater need for material to be more interesting for a lecture to be effective.

\section{Middlers:}

- express a significant preference to be taught with more lecture than active techniques.

- do desire a combination of AL and TL but are geared toward efficient, directed learning.

- clearly recognize that material is retained better with AL but value organized lecture more.

- express a higher appreciation for structure, clarity, and RW examples than other groups.

- have a relatively low concern for the demeanor of the professor as long as they are fair, organized, and easily understood in terms of clarity of presentation and speech intelligibility.

\section{Seniors:}

- strongly tend back to hands-on learning, preferring it significantly over traditional lecture.

- desire a balance across factors in this order: hands-on active methods, examples for real-world application, organization of material, clarity of presentation, professor's manner, and pace.

- attest that their desire for experiential learning relates to preparing to enter the workforce.

- expressed the concept of 'pace' to a greater degree than others (yet it was a small factor).

\section{Considerations and Future Recommendations}

There are several other factors beyond basic class level and course type that will likely have an additional bearing on the results and conclusions of this work. Some of those may be learning style, major, class topic, individual and collective motivating factors, and the number of students in a course. We have collected data on these factors as well and it is proposed that some of these variables will be explored as part of this ongoing research. Clearly, some of the responses have better context in light of other questions and their answers, but this is a start to help us as educators ask the right questions and be discerning in terms of which teaching methods map best with our students at progressive levels in engineering education.

\section{Summary and Conclusions}

The purpose of this research was to (1) outline the development of "age-specific" learning models, (2) acknowledge the objective evidence supporting the merits of experiential learning, (3) assess trends among effective teaching methods in first-year, third-year, and fifth-year university students in engineering, and (4) offer guidelines to educators on how to better structure a course so as to harness the various learning needs and desires of students across all learning levels and through the academic maturation process. In summary, freshmen engineering students desired a higher percentage of active learning for the purposes of engagement, interest, and guidance; middler students desired a higher percentage of traditional lecture on the basis of foundation, instruction, and efficient dissemination of the material; senior students demonstrate a shift back to AL, preferring a higher percentage of active, experiential learning for the benefits of practical, real-world application. This in fact maps well to Vygotsky's Zone of Proximal Development in terms of transcending from guided instruction to selfdirected learning ${ }^{9,12}$. The primary clarifier is noting how active learning is used to accomplish this shift across the learning continuum. 
This paper briefly reviewed the sociological origins of immediate motivations for and contributors to learning, analyzed andragogical and pedagogical trends among multiple levels of students participating in Northeastern University's five-year academic program, and related the findings to a proposed optimal balance of active learning techniques for the progressive academic levels. While the decision concerning the combination of learning modes and how they ought to be mixed is certainly a function of many factors -and is ultimately the decision of the educator- this work provides another piece in the puzzle for consideration in the trend toward responsive and responsible engineering education. Our initial inclination that freshmen "needed" more active learning with a subsequent proportional reduction across the duration of the engineering curriculum was altered by the strength of the profiles that emerged from the our students' feedback.

We are able to identify where our original hypothesis went "wrong" by gaining new insight. A tool for course construction that we can use as educators is to manage our long-term educational objectives for the students with a concomitant focus on the immediate goal of a given student population when we design our curricula. We have learned that we need to be flexible in our thinking, understanding that some solutions solve more than one problem. Thus, in knowing that freshmen need to find a connection to the course and the program, the course design should be interesting and illustrative and therefore ALoriented. Knowing that middlers are hungry for information, the desire for its efficient delivery shifts the lever back to TL. Then finally the seniors' desire to enter the real world running returns the course structure back to the realm of experiential education.

As educators, we could make an error in our formulations if we confuse the meaning of maturation as equating to a need to take on detail and information with diminishing levels of engagement. The real point to be considered is what is the academic maturation process preparing its subject for, and what are the stages of that development? The answers to these questions more directly help educators identify a suitable mix for their courses. Through a better understanding of learning engagement and its catalysts across the academic levels, we as educators will be able to gain more insight into the balance required for various teaching techniques in an "age-appropriate" manner.

These findings will be further tested with additional educational research and more extensive data analysis as a continuation of this research and for publication. This work is intended to assist newer faculty members-and hopefully enlighten some of our experienced educators- in making classroom-style decisions in relation to their courses and the level and needs of the students they are teaching. This research shows that it is essential to make the correct correlations between modes of teaching, academic motivation, and modes of learning to identify the most effective educational methods and their appropriate proportional use; it is also a step toward addressing the maturation process of learning in young engineers. 


\section{References}

[1] Felder, R. \& Brent, R. (2003). Learning by Doing. Chemical Engineering Education, 37:4, 282-283.

[2] Freeman, S., Whalen, R. \& Jaeger, B.K. (2006). Active Teaching, Active Learning: Infusing the Design Process in a First-Year Course. Proceedings of the American Society of Engineering Education. Chicago, IL.

[3] Hartley, J. \& Davies, I.K. (1986). Note-taking: A Critical Review. Programmed Learning and Education Technology, 15, 207.

[4] Knowles, M. (1980). The Modern Practice of Adult Education: from Pedagogy to Andragogy. Englewood Cliffs, NJ: Prentice Hall Regents.

[5] Jaeger, B.K., Whalen, R., \& Freeman, S. (2007). Do they Like What They Learn, Do They Learn What They Like - And What Do We Do About It? Proceedings of the American Society of Engineering Education, Honolulu, HI.

[6] McCarthy, J.P. \& Anderson, L. (2000). Active Learning Techniques Versus Traditional Teaching Styles: two experiments from history and political science. Innovative Higher Education, 24:4, 279-294.

[7] McKeachie, W. (1999). Teaching Tips: Strategies, Research, and Theory for College and University Teachers. $10^{\text {th }}$ Edition. Boston: Houghton Mifflin.

[8] Meade, G.H. (1934/1962). Mind, Self, and Society: From the Standpoint of a Social Behaviorist. Chicago: University of Chicago Press.

[9] Morris, C. (1998). Lev Semoyonovich Vygotsky's Zone of Proximal Development. PhiDelta Kappa News (February/March Issue).

[10] Raines, S. \& Rochester, J.M. (2003). The Potential Perils of Slack (not Pack) Pedagogy: A response to J. Martin Rochester's remarks about active learning strategies. International Studies Perspectives, 4, 432-435.

[11] Ritzer, G. (2000). Classical Sociological Theory. New York, NY: The McGraw-Hill Companies, Inc.

[12] Vygotsky, L. (1978). Mind in Society. Cambridge, MA: Harvard University Press.

Special acknowledgement for this research goes to two Northeastern undergraduate students co-authoring this work, Brittany Damon and Alison Reppy. Brittany sought out and initiated this project above and beyond her academic course load in her Junior and Senior year. Alison volunteered as a Senior to participate in this initiative above and beyond her academic load as well. 


\section{APPENDIX A \\ Survey Tool}

Notes:

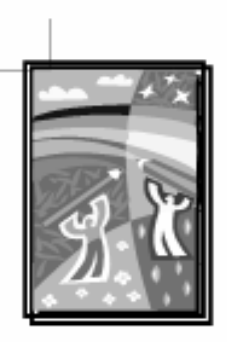

\section{ACTIVE LEARNING VS. TRADITIONAL LECTURE}

PURPOSE: To gain a better understanding of the features of active learning techniques in the classroom in comparison to lecturing in person (not on line or video), identify the most effective combination of such techniques for different academic levels, and to determine the level of correlation between techniques in freshman and seniors.

DIRECTIONS: Please answer questions below to the best of your ability and as thoroughly as possible. Your honesty is extremely appreciated.

$\begin{array}{llll}\text { Gender (circle one): } & \text { Male } & \text { Female } & \text { Age: } \\ { } } & \text { Sophomore } & \text { Middler Junior Senior } \\ \text { QPA: } & & & \text { Major: }\end{array}$

1. Do you consider lecturing to be an effective method of teaching?

\begin{tabular}{|l|l|l|c|c|c|c|}
\hline Not at all & Sometimes & $\begin{array}{c}\text { A little less than } \\
\text { half the time }\end{array}$ & $\begin{array}{c}\text { About 50\% } \\
\text { of the time }\end{array}$ & $\begin{array}{c}\text { A little more than } \\
\text { half the time }\end{array}$ & $\begin{array}{c}\text { Most of } \\
\text { the time }\end{array}$ & Totally \\
\hline
\end{tabular}

1a. What makes one person's lecture (not just their class) better than another's?

1b. Is there a type of engineering class that is better suited to lecture format than others?

2. Do you consider the use of active learning techniques (hands-on activities, serious games, group activities, other experiential learning modes) an effective method of teaching in engineering?

\begin{tabular}{|l|l|c|c|c|c|c|}
\hline Not at all & Sometimes & $\begin{array}{c}\text { A little less than } \\
\text { half the time }\end{array}$ & $\begin{array}{c}\text { About 50\% } \\
\text { of the time }\end{array}$ & $\begin{array}{c}\text { A little more than } \\
\text { half the time }\end{array}$ & $\begin{array}{c}\text { Most of } \\
\text { the time }\end{array}$ & Totally \\
\hline
\end{tabular}

2a. Is there a type of engineering class that is better suited to active learning than others?

3. Do you enjoy classes more when active learning techniques are used?

\begin{tabular}{|l|l|c|c|c|c|c|}
\hline Not at all & Sometimes & $\begin{array}{c}\text { A little less than } \\
\text { half the time }\end{array}$ & $\begin{array}{c}\text { About } 50 \% \\
\text { of the time }\end{array}$ & $\begin{array}{c}\text { A little more than } \\
\text { half the time }\end{array}$ & $\begin{array}{c}\text { Most of } \\
\text { the time }\end{array}$ & Totally \\
\hline
\end{tabular}

4. Do you learn more in classes that utilize active learning techniques?

\begin{tabular}{|c|c|c|c|c|c|c|}
\hline Not at all & Sometimes & $\begin{array}{c}\text { A little less than } \\
\text { half the time }\end{array}$ & $\begin{array}{c}\text { About } 50 \% \\
\text { of the time }\end{array}$ & $\begin{array}{c}\text { A little more than } \\
\text { half the time }\end{array}$ & $\begin{array}{c}\text { Most of the } \\
\text { time }\end{array}$ & Totally \\
\hline
\end{tabular}


5. How motivated are you to come to class knowing your professor will spend the entire $60+$ minute class lecturing?

\begin{tabular}{|c|c|c|c|c|c|c|}
\hline $\begin{array}{c}\text { Not at all } \\
\text { motivated }\end{array}$ & $\begin{array}{c}\text { Mostly } \\
\text { unmotivated }\end{array}$ & $\begin{array}{c}\text { Slightly } \\
\text { unmotivated }\end{array}$ & Neutral & $\begin{array}{c}\text { Slightly } \\
\text { motivated }\end{array}$ & $\begin{array}{c}\text { Mostly } \\
\text { motivated }\end{array}$ & $\begin{array}{c}\text { Very } \\
\text { motivated }\end{array}$ \\
\hline
\end{tabular}

5a. Is your above answer affected by which professor is doing the lecturing? Yes | No Comment:

6. Do you frequently lose focus during lecture-based classes?

\begin{tabular}{|c|c|c|c|c|c|c|}
\hline $\begin{array}{c}\text { Yes, every } \\
\text { class }\end{array}$ & $\begin{array}{c}\text { Nearly every } \\
\text { class }\end{array}$ & Most classes & $\begin{array}{c}\text { About 50\% } \\
\text { of classes }\end{array}$ & $\begin{array}{c}\text { Some } \\
\text { classes }\end{array}$ & Hardly ever & Never \\
\hline
\end{tabular}

6a. Does your answer to Question 6 change for different types of engineering classes? Why?

7. Do active learning techniques help to improve your focus throughout the class?

\begin{tabular}{|l|l|l|l|l|l|c|}
\hline Not at all & Sometimes & $\begin{array}{c}\text { A little less than } \\
\text { half the time }\end{array}$ & $\begin{array}{c}\text { About 50\% } \\
\text { of the time }\end{array}$ & $\begin{array}{c}\text { A little more than } \\
\text { half the time }\end{array}$ & $\begin{array}{c}\text { Most of } \\
\text { the time }\end{array}$ & Totally \\
\hline
\end{tabular}

8. What are some of your most memorable class activities in which you were engaged and leamed the material effectively (not just enjoyed the exercise)? What were the advantages of this?

$\begin{array}{ll}\text { Course: } & \text { Year }(\mathrm{Fr}, \mathrm{Jr}, \text { etc.) } \\ \text { Activity: } & \\ \text { Benefit: } & \\ \text { Course: } & \text { Year }(\mathrm{Fr}, \mathrm{Jr}, \text { etc.) } \\ \text { Activity: } & \\ \text { Benefit: } & \\ \text { Course: } & \text { Year }(\mathrm{Fr}, \mathrm{Jr}, \text { etc.) } \\ \text { Activity: } \\ \text { Benefit: }\end{array}$

9. With percentages that sum to 100 , create your ideal combination of teaching techniques for your current academic year. Ex). 1\% active learning I $99 \%$ lecture and briefly explain why below.

\section{Explanation:}

9a. Would you change this balance for different courses or academic levels? Explain, in percentages. 
10. What motivates you to learn (i.e. personal interest, games/competition, interaction with others, desire to score high, an interest in learning in general, the professor, etc.)? You may use your own words as well and you may have more than one motivation. How? Why?

Motivation:

Explanation:

11. How would you describe your leaming style? Placing a rating number next to each of the following, adding any additional ones if you choose: Rate each from most dominant (1) to least dominant (5) for you
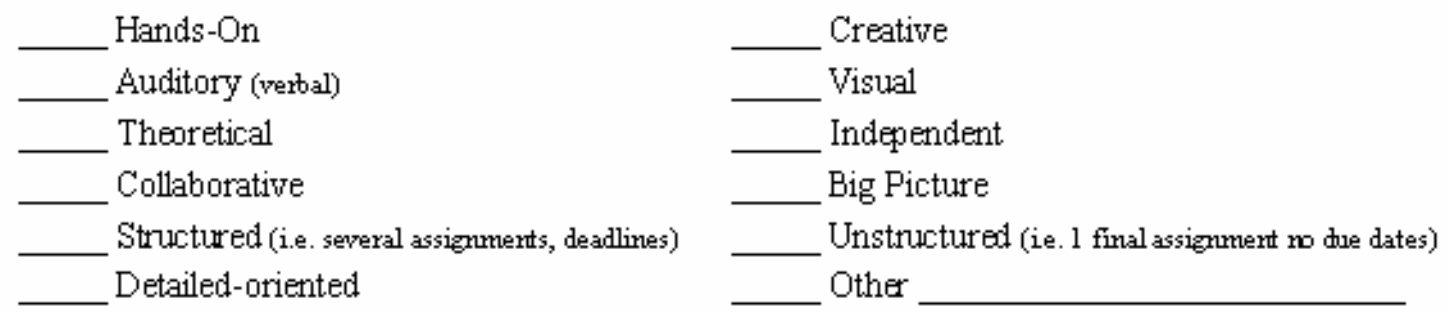

12. What teaching techniqua (s) would most help to improve your retention of course material at your current level in your education? This may include a combination of styles (refer to your answers from question 11 above). Please explain: 